НАУКОВИЙ ВІСНИК

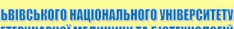

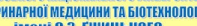
імені с.з. гжицького Scientific messenger of L Liv National Iniversity of
Veterinary Medicine and Biotechnologies

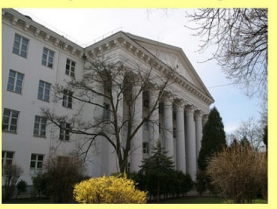

СЕРЯЯ "ЕКОНОМччН НАУКИ"

Том 22 № 96 2020
Науковий вісник Аьвівського національного університету ветеринарної медицини та біотехнологій імені С.3. Гжицького. Серія: Економічні науки

\author{
Scientific Messenger of Lviv National University \\ of Veterinary Medicine and Biotechnologies. \\ Series: Economical Sciences
}

\title{
Diversification as a tool for sustainable development of rural areas in the context of decentralization
}

\author{
N. Khomiuk ${ }^{1}$, N. Pavlikha ${ }^{1}$, I. Voronyj ${ }^{2}$ \\ ${ }^{1}$ Lesya Ukrainka Volyn National University, Lutsk, Ukraine \\ ${ }^{2}$ Stepan Gzhytskyi National University of Veterinary Medicine and Biotechnologies Lviv, Lviv, Ukraine
}

Article info

Received 16.11.2020

Received in revised form 17.12.2020

Accepted 18.12.2020

Lesya Ukrainka Volyn National University, Voli avenue, 13, Lutsk, 43025, Ukraine.

Tel.: +38-050-500-89-25

E-mail:nataljabilous@gmail.com

Stepan Gzhytskyi National University of Veterinary Medicine and Biotechnologies Lviv, Pekarska Str., 50, Lviv, 79010, Ukraine.
Khomiuk, N., Pavlikha, N., \& Voronyj, I. (2020). Diversification as a tool for sustainable development of rural areas in the context of decentralization. Scientific Messenger of Lviv National University of Veterinary Medicine and Biotechnologies. Series: Economical Sciences, 22(96), 35-41. doi: 10.32718/nvlvet-e9606

The article substantiates diversification as a tool to ensure sustainable development of rural areas in decentralization, which contributes to increasing incomes of the rural population, increasing gross agricultural and non-agricultural products, ensuring the competitiveness of rural areas, achieving economic, food and environmental safety, rational use, protection and reproduction of natural resources. In the process of researching the level of sustainable development of rural areas, monographic and graphic methods and scientific generalization were used. The study identified internal factors that affect the sustainable development of rural areas. Social factors include living conditions, the situation on the labor market, the state of social infrastructure. Economic factors should include the provision of agricultural land, the state of diversification of agricultural and non-agricultural activities, the amount of investment in economic development, the level and structure of household income in rural areas. Environmental factors include the level of air pollution, the situation with waste, the use of freshwater, the application of fertilizers to soils, the production and restoration of forests, the level of investment in environmental protection. External factors influencing the sustainable development of rural areas include the political situation in the country and the world; decentralization process; state programs to support rural development and agriculture; the level of supply and demand for goods and services produced in a particular area, etc. It is substantiated that diversification is a tool to ensure sustainable development and strengthen the competitive advantages of rural areas. It is stipulated that attracting investments in rural development and diversification of economic activity will contribute to job creation; income growth of rural residents; the revival of local crafts, customs and crafts, improvement of villages and change of consciousness of villagers. Further research should be carried out in the direction of calculating the integrated index of sustainable development of rural areas in Ukraine to identify regional disparities in the social, economic and environmental spheres of the functioning of these areas in the context of decentralization.

Key words: rural areas, sustainable development, diversification, rural population, agriculture.

\section{Диверсифікація як інструмент забезпечення сталого розвитку сільських територій в умовах децентралізації}

\author{
Н. Хомюк ${ }^{1}$ Н. Павліха ${ }^{1}$, I. Вороний ${ }^{2}$ \\ ${ }^{1}$ Волинський національний університет імені Лесі Украйнки, м. Луияьк, Украӥна \\ ${ }^{2}$ Львівський національний університет ветеринарної медицини та біотехнологій імені С. 3. Гжицького, м. Львів, \\ Україна
}

У статті обтрунтовано диверсифікаџію як інструмент забезпечення сталого розвитку сільських територій в умовах децентралізації, щзо сприяє зростанню доходів сільського населення, збільшенню обсягів валової сільськогосподарської та несільськогос- 
подарської продукиії, забезпеченню конкурентоспроможності сільських територій, досягненню економічної, продовольчої та екологічної безпеки, раціональному використанню, охороні та відтворенню природних ресурсів. У процесі проведення досліджень рівня сталого розвитку сільських територій використано монографічний та графічний методи, й наукового узагальнення. В результаті дослідження виявлено внутрішні чинники, які впливають на сталий розвиток сільських територій. До сочіальних чинників віднесено умови життя населення, ситуачію на ринку праці, стан сочіальної інфраструктури. До економічних чинників дочільно включити забезпеченість сільськогосподарськими угіддями, стан диверсифікації сільськогосподарської та несільськогосподарської діяльності, обсяг інвестицій у розвиток економіки, рівень та структуру доходів домогосподарств на сільських територіях. До екологічних чинників віднесено рівень забруднення атмосферного повітря, ситуацію з відходами, використанням прісної води, внесенням добрив у трунти, виробкою та відновленням лісів, рівень обсягів інвестицій на охорону навколишнього природнього середовища. До зовнішніх чинників впливу на сталий розвиток сільських територій віднесено політичне становище в країні та світі; процес децентралізації; державні програми підтримки розвитку сільської місцевості й сільського господарства; рівень попиту та пропозиції на товари й послуги, які виробляються на певній території тощо. Обтрунтовано, щуо диверсифікація є інструментом забезпечення сталого розвитку та посилення конкурентних переваг сільських територій. Обумовлено, щзо залучення інвестицій у розвиток сільських територій і диверсифікація економічної діяльності сприятимуть створенню робочих місць; зростанню доходів сільських жителів; відродженню місиевих народних промислів, звичаїв та ремесл, покращенню благоустрою сіл $і$ зміні свідомості сільських жителів. Подальші дослідження доцільно здійснювати у напрямі розрахунку інтегрального індексу сталого розвитку сільських територій в Украӥні з метою виявлення регіональних диспропорцій у соціальній, економічній та екологічній сферах функціонування циих територій в умовах децентралізації.

Ключові слова: сільські території, сталий розвиток, диверсифікація, сільське населення, сільське господарство.

\section{Ветуп}

Дослідження сучасних процесів розвитку сільських територій як складних соціо-економікоекологічних систем є важливим з огляду на необхідність вирішення існуючих соціально-економічних та екологічних проблем, серед яких - високий рівень безробіття, несприятлива демографічна ситуація, міграційні процеси, дефіцити і нерозвинутість закладів соціальної інфраструктури, низька рентабельність сільськогосподарського та несільськогосподарського виробництва тощо. Реалізація реформи децентралізації в Україні сприяє розширенню прав, повноважень та ресурсних можливостей органів місцевого самоврядування та надають можливість кожній територіальній громаді самостійно обирати стратегію й вектори свого розвитку. При цьому розробка нових підходів до організаційно-економічного забезпечення розширеного відтворення сільських територій в умовах децентралізації сприятиме досягненню цілей їх сталого розвитку, збереженню місцевих звичаїв, історичних та етнічних особливостей.

В Україні теоретико-методологічні та прикладні аспекти організаційного та економічного забезпечення сталого розвитку сільської місцевості глибоко розкривають такі вчені, як О. Бородіна, М. Долішній, Ю. Лупенко, А. Малиновський, О. Онищенко, О. Павлов, Х. Притула, О. Попова, I. Прокопа, О. Шубравська, М. Хвесик, В. Юрчишин, інші. У переважній більшості вітчизняними дослідниками при розкритті концептуальних засад сталого розвитку сільських територій увага домінує на проблематиці якості довкілля. На думку вчених, під сталим розвитком розуміють установлення гармонійних і збалансованих стосунків між людиною, суспільством та природою, тобто тріаду збалансованих векторів розвитку - соціального, економічного, екологічного. Звернемо увагу, що попри вагомий теоретичний і прикладний здобуток учених із зазначеної тематики, потребують поглибленого вивчення питання науковообгрунтованого вибору того чи іншого напряму диверсифікації розвитку сільських територій відповідно до стратегії їх сталого розвитку.
Метою дослідження є науково-методичне обгрунтування концептуальних засад диверсифікації як інструменту забезпечення сталого розвитку сільських територій в умовах децентралізації. Їх запровадження сприятиме зростанню доходів сільського населення, збільшенню обсягів валової сільськогосподарської та несільськогосподарської продукції, забезпеченню конкурентоспроможності сільських територій, досягненню економічної, продовольчої та екологічної безпеки, раціональному використанню, охороні та відтворенню природних ресурсів.

Для досягнення поставленої мети вирішуються наступні завдання: розкрити парадигму сталого розвитку сільських територій на засадах диверсифікації розвитку цих територій, оцінити стан соціального, економічного та екологічного розвитку сільських територій в Україні, обгрунтувати значення процесу диверсифікації для досягнення сталого розвитку цих територій.

\section{Матеріал і методи досліджень}

У процесі проведення досліджень використано загальнонаукові методи, серед яких: монографічний при теоретичному обгрунтуванні дефініцій “сталий розвиток сільських територій” та “диверсифікація”; економіко-статистичний, графічний - для виявлення сучасних тенденцій соціального, економічного та екологічного розвитку сільських територій в Україні, наукового узагальнення - при обгрунтуванні диверсифікації як дієвого інструменту забезпечення сталого розвитку сільських територій.

\section{Результати та їх обговорення}

В умовах трансформації сучасних економічних систем у світовий економічний простір важливого значення набувають проблеми забезпечення сталого розвитку територій. За матеріалами доповіді Всесвітньої комісії з навколишнього середовища та розвитку "Наше спільне майбутне” у 1987 р. “сталий розвиток - це такий розвиток, який забезпечує потреби сучасності, але при цьому не впливає на можливість майбутніх поколінь задовольняти свої власні 
потреби" (Report of the World Commission on Environment and Development, 1987).

Концепція сталого розвитку здобула визначення завдяки дослідженням Римського клубу й працям Дж. Меддоуз "Межі зростання" (1972 р.) та "За межами зростання” (1992р.). Вирішальне значення для закладення вихідних принципів сталості мала Конференція $\mathrm{OOH} \mathrm{із} \mathrm{проблем} \mathrm{навколишнього} \mathrm{середовища} \mathrm{та} \mathrm{розви-}$ тку 1992 р. у Ріо-де-Жанейро, на якій офіційно прийнято стратегію переходу від економічного зростання до сталого розвитку “Agenda 21” (“План дій на XXI століття”). Прийняті рекомендації включали главу “Підтримка сталого розвитку сільського господарства та сільських регіонів”. У 2002 р. в Йоганнесбурзі відбувся Всесвітній саміт із проблем сталого розвитку "Ріо+10", на якому обговорювалися проблеми реалізації програм сталого розвитку в розвинених країнах. Велику увагу в цих державах приділяли покращенню екологічної ситуації та збереженню природних основ життєдіяльності за рахунок перерозподілу фінансових ресурсів з інших сфер діяльності. У березні 2010 р. Європейський Союз прийняв оновлену стратегію сталого розвитку під назвою “Свропа-2020”, у якій викладено Концепцію соціальної ринкової економіки для Європи у XXI ст. Сталий розвиток визначається як один із трьох найбільш важливих факторів економічного зростання поряд із “розумним” розвитком (Borodina, 2012).

В. Загорський та $€$. Борщук вважають, що “сталий розвиток сільських територій повинен відбуватися на основі модернізації виробничої інфраструктури, підвищення рівня зайнятості сільського населення, зменшення трудової міграції, підвищення конкурентоспроможності сільськогосподарського виробництва, покращення якості і безпеки сільськогосподарської продукції, поліпшення екологічної ситуації у сільській місцевості та забезпечення високого рівня відтворення природних ресурсів. Йому необхідна наявність зваженого підходу до державного регулювання розвитку сільських територій, із урахуванням їх особливостей, 3 метою створення умов для саморозвитку та активізації людського потенціалу" (Zahorskyi \& Borshchuk, 2019).

Сталий розвиток сільських територій, на думку I. Федуняка та О. Підлужної, можливий за умов виконання прийнятих нормативних актів, збалансованого росту економіки, розширення несільськогосподарської зайнятості в сільській місцевості, основою якого є зелений туризм, поліпшення умов доступу господарських суб'єктів підприємницької діяльності на селі до ринків ресурсів, де головною метою є створення умов для зростання благополуччя населення й формування сприятливого соціального та економічного середовища на селі (Feduniak \& Pidluzhna, 2019).

О. Бородіна під сталим розвитком сільської місцевості вбачає “стабільний розвиток сільської громади, що зумовлює виконання функцій забезпечення продовольством, виробництва сільськогосподарської сировини та несільськогосподарських товарів і послуг, забезпечення суспільних благ - збереження сільського укладу життя, надання соціальних послуг, соціальний контроль над територією, збереження історично освоєних ландшафтів; розширене відтворення населення, підвищення добробуту й рівня задоволеності”. Погоджуємось 3 ïï думкою, що “реформування чинної системи державного регулювання в сільському господарстві має відповідати таким вимогам сталого розвитку, як децентралізація влади, регіональний маркетинг, інституціональні перетворення, реструктуризація агропродовольчого сектору, диверсифікація економіки, функціональна інтеграція та планування землекористування" (Borodina, 2012).

Ю. Лупенко вважає, що “для забезпечення сталого розвитку селянам потрібно надати можливість реалізовувати власну підприємницьку ініціативу, передусім у сільському господарстві, через розвиток сімейного фермерства й багатоукладного виробництва. Завдяки цьому на селі якісно та кількісно збільшиться середній клас, а фінансово спроможні, ініціативні сільські громади спрямовуватимуть свою діяльність на забезпечення високої якості життя сільських жителів і збереження довкілля". Сукупно зазначені компоненти моделі (селянин-власник, потужний середній клас, фінансово та соціально спроможна сільська громада) у поєднанні з ефективною державною політикою, на його думку, можуть і повинні забезпечити сталий розвиток сільських територій (Lupenko, 2017).

Л. Акімова та інші науковці провели дослідження особливостей планування соціально-економічного розвитку сільських територій Болгарії, Естонії, Латвії, Литви, Польщі, Румунії, Словаччини, Угорщини, Хорватії та Чехії (Akimova et al., 2020), результати яких можуть бути використані для адаптації досвіду цих країн для досягнення перспектив сталого розвитку цих територій.

Аналіз процесів реалізації Державної стратегії регіонального розвитку й Концепції розвитку сільських територій дозволив виявити неспроможність подолання суперечностей між необхідністю фінансувати поточні витрати та витрати, які пов'язані із забезпеченням стратегічних цілей сталого розвитку. Процеси децентралізації влади й створення ОТГ в цих умовах можуть надати позитивні зрушення в бік виконання стратегічних цілей, які пов'язані з розвитком сільських територій, адже кожна громада може та повинна самостійно оцінити поточний соціально-економічний стан і спрямувати кошти на вирішення нагальних потреб населення.

Термін “диверсифікація” широко використовується в науковій літературі. Проте не існує чіткого формулювання цієї дефініції, адже вона виступає предметом дослідження багатьох наук (географічних, економічних, соціальних, екологічних та ін.). В системі ринкових відносин проявляються різні аспекти диверсифікації.

Вважаємо, що парадигму сталого розвитку сільських територій доцільно покласти в основу розробки концепції диверсифікації розвитку цих територій, побудованої на засадах комплексності, міждисциплінарності та синергетики, цільовим орієнтиром якої $\epsilon$ ефективне використання наявних i потенційних можливостей розвитку сільських територій для підвищення якості життя сільського населення; посилення конкурентних переваг цих територій та досяг- 
нення екологічної безпеки в умовах децентралізації (Khomiuk \& Pavlikha, 2019). В процесі дослідження здійснено аналіз сталого розвитку сільських територій в умовах децентралізації на основі застосування методики, яка грунтується на визначення часткових індексів розвитку соціальної сфери, економічної та екологічної ситуацій та розрахунку на їх основі інтегрального індексу сталого розвитку сільських територій України (Khomiuk et al., 2020).

Обгрунтовано, що на сільських територіях диверсифікація грунтується на передислокації ресурсів у нові напрями сільськогосподарської й несільськогос- подарської діяльності. Тому розширення асортименту та ринків збуту сільськогосподарської продукції, органічне виробництво, вирощування нішевих культур сприятимуть диверсифікації сільськогосподарського виробництва на засадах сталого розвитку та забезпечать зростання експорту продукції, розширення сфер зайнятості і, відповідно, доходів сільського населення (Khomiuk, \& Pavlikha, 2020).

3 метою виокремлення напрямів диверсифікації розвитку сільських територій в умовах децентралізації здійснено класифікацію іiі видів за сферою впливу, що відображено у табл. 1.

\section{Таблиця 1}

Взаємозв’язок видів та напрямів диверсифікації розвитку сільських територій в умовах децентралізації

\begin{tabular}{|c|c|c|c|c|}
\hline \multirow{2}{*}{$\begin{array}{c}\text { Вид } \\
\text { диверсифі- } \\
\text { кації }\end{array}$} & \multicolumn{3}{|c|}{ Характеристика особливостей диверсифікації } & \multirow{2}{*}{$\begin{array}{l}\text { Напрям диверсифі- } \\
\text { кації розвитку сіль- } \\
\text { ських територій в } \\
\text { умовах децентралі- } \\
\text { зації } \\
\end{array}$} \\
\hline & на рівні держави & $\begin{array}{c}\text { на рівні сільської } \\
\text { території }\end{array}$ & на рівні підприємства & \\
\hline \multirow{2}{*}{ Галузева } & \multirow{2}{*}{\multicolumn{2}{|c|}{$\begin{array}{c}\text { Розвиток та підтримка сільськогосподарського та } \\
\text { несільськогосподарського виробництва, розробка } \\
\text { регіональної стратегії на засадах смарт спеціалізації, } \\
\text { виокремлення пріоритетних галузей розвитку для } \\
\text { сільських територій }\end{array}$}} & \multirow{2}{*}{$\begin{array}{c}\text { Розвиток на базі підпри- } \\
\text { ємства пов'язаних або } \\
\text { непов'язаних між собою } \\
\text { напрямів діяльності, } \\
\text { розширення ринків } \\
\text { збуту та асортименту } \\
\text { продукції }\end{array}$} & $\begin{array}{c}\text { Диверсифікація } \\
\text { сільськогоспо- } \\
\text { дарського виробни- } \\
\text { цтва } \\
\end{array}$ \\
\hline & & & & $\begin{array}{c}\text { Диверсифікація } \\
\text { несільськогос- } \\
\text { подарської діяльнос- } \\
\text { ті }\end{array}$ \\
\hline $\begin{array}{c}\text { Фінансово- } \\
\text { інвестиці- } \\
\text { йна }\end{array}$ & $\begin{array}{c}\text { Формування Державно- } \\
\text { го та обласних бюдже- } \\
\text { тів, розподіл коштів між } \\
\text { регіонами та пріоритет- } \\
\text { ними галузями, міжна- } \\
\text { родна фінансова спів- } \\
\text { праця, здійснення фор- } \\
\text { вардних закупівель }\end{array}$ & $\begin{array}{c}\text { Формування місцевих } \\
\text { бюджетів, розподіл кош- } \\
\text { тів між пріоритетними } \\
\text { галузями на рівні ОТГ, } \\
\text { залучення коштів міжна- } \\
\text { родних організацій, юри- } \\
\text { дичних та фізичних осіб, } \\
\text { проектне фінансування }\end{array}$ & $\begin{array}{c}\text { Перерозподіл фінансо- } \\
\text { вих ресурсів (прибутку, } \\
\text { статутних та пайових } \\
\text { внесків) між підрозді- } \\
\text { лами підприємства, } \\
\text { залучення коштів інших } \\
\text { організацій (інвестицій, } \\
\text { кредитів) } \\
\end{array}$ & $\begin{array}{c}\text { Диверсифікація } \\
\text { джерел фінансуван- } \\
\text { ня розвитку сільсь- } \\
\text { ких територій }\end{array}$ \\
\hline $\begin{array}{c}\text { Організа- } \\
\text { ційно- } \\
\text { правова }\end{array}$ & $\begin{array}{r}\text { Підтримка створення юр } \\
\text { сільських територіях, пе } \\
\text { фермерські господарств } \\
\text { співпраці ОТГ з метою } \\
\text { зей е }\end{array}$ & $\begin{array}{l}\text { ичних та фізичних осіб на } \\
\text { реєстрація підприємців у } \\
\text { рормування кластерів для } \\
\text { витку пріоритетних галу- } \\
\text { номіки }\end{array}$ & $\begin{array}{c}\text { Перехід в іншу органі- } \\
\text { заційно-правову форму } \\
\text { господарювання, ство- } \\
\text { рення інтеграційних } \\
\text { структур }\end{array}$ & $\begin{array}{c}\text { Диверсифікація } \\
\text { організаційно- } \\
\text { правових форм } \\
\text { господарювання }\end{array}$ \\
\hline
\end{tabular}

Джерело: розроблено авторами.

Усі види диверсифікації доповнюють один одного та взаємопов'язані між собою. Пропонуємо такі напрями диверсифікації сталого розвитку сільських територій в умовах децентралізації, як:

- диверсифікація сільськогосподарського виробництва; сті;

- диверсифікація несільськогосподарської діяльно-

- диверсифікація організаційно-правових форм господарювання;

- диверсифікація джерел фінансування розвитку сільських територій.

Звернемо увагу, що вибір того чи іншого напряму диверсифікації розвитку сільських територій повинен відповідати обгрунтованим соціально-, економіко- та екологічно-орієнтованим стратегічним цілям. Так, результати соціально-орієнтованої диверсифікації виражаються у підвищенні рівня зайнятості на селі, подоланні бідності, розвитку соціальної інфраструктури, підвищенні якості надання послуг, забезпеченні життєдіяльності сільських жителів, підвищенні освітнього та культурного рівнів сільського населення.

У свою чергу, економіко-орієнтована диверсифікація має на меті не лише отримання прибутку, але й збільшення обсягів сільськогосподарського та несільськогосподарського виробництва, досягнення продовольчої та економічної безпеки, підвищення конкурентоспроможності продукції та послуг, створення умов щодо залучення інвестицій. Результатами екологічно-орієнтованої диверсифікації виступають раціональне використання, охорона та відтворення природних ресурсів; поширення органічного виробництва; зменшення деструктивного впливу на довкілля. При цьому, на відміну від результатів економічноорієнтованої диверсифікації розвитку сільських територій, ефект від соціально- та екологічно-орієнтованої диверсифікації може лише частково набувати грошової форми.

Узагальнюючим критерієм, який характеризує сталий розвиток сільських територій, є якість життя 
людей на цих територіях. Важливим соціальним параметром сталого розвитку сільських територій $\epsilon$ загальний приріст (скорочення) сільського населення. У 2018 р. в Україні спостерігалося загальне скорочення сільського населення на 118,9 тис. осіб за рахунок природного (108,2 тис.) та міграційного (10,7 тис.) скорочення. Міграційний приріст сільських жителів спостерігався у Київській (13,7 тис.), Львівській (1,9 тис.), Волинській (0,6 тис.) та Одеській (0,2 тис.) областях, а в інших регіонах відбулось скорочення сільських мешканців за рахунок міграції.

Головна проблема сільських жителів полягає в тому, що їхнє фінансове становище більш складне, по- рівняно $з$ міським населенням. Про низький рівень життя сільських мешканців України свідчить такий показник, як частка населення із середньодушовими еквівалентними грошовими доходами на місяць нижчими від фактичного прожиткового мінімуму: якщо загалом по Україні у 2018 р. це 38,6 \%, то в сільській місцевості - 48,4\%. Рівень безробіття на сільських територіях у 2018 р. становив 9,2\%, що на $0,7 \%$ менше, порівняно $з$ у 2017 р. Найвищий рівень безробіття зареєстровано в Донецькій та Полтавській областях, а найнижчий - в Чернівецькій. Рівні зайнятості та безробіття на сільських територіях в регіонах України у 2018 р. відображено на рис. 1 .

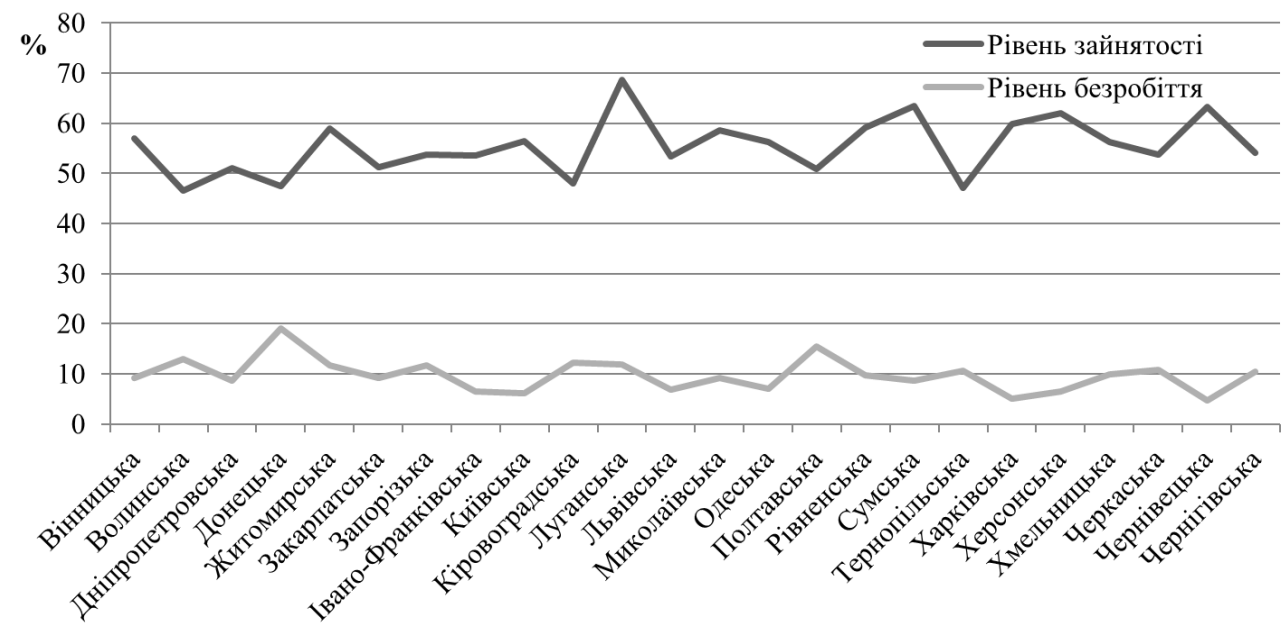

Рис. 1. Рівні зайнятості та безробіття на сільських територіях у регіонах України у 2018 р. Джерело: побудовано авторами на основі статистичних даних (Derzhavna sluzhba statystyky Ukrainy, 2019)

Прерогативою розвитку сільських територій є покращення, передусім, умов життєдіяльності селян (оскільки крім сільського господарства, розвиток села охоплює ще й інші сфери, наприклад освіту, охорону здоров'я, довкілля, інфраструктуру та ін.). Відзначимо, що спостерігається динаміка зменшення кількості дошкільних навчальних закладів у сільській місцевості 3 9,3 тис. у 2014 р. до 9,1 тис. у 2018 р. та зменшення чисельності дітей у цих закладах 3326 тис. у 2014 р. до 309 тис. у 2018 р. Загалом по Україні дошкільними закладами освіти охоплено лише $41 \%$ сільських дітей відповідного віку. На рис. 1 відображено тенденцію охоплення дітей закладами дошкільної освіти на сільських територіях у регіонах України в 2018 р. Найбільше дошкільнят залучено до освіти у Київській, Черкаській, Херсонській та Миколаївській областях. Спостерігаємо не лише зменшення кількості дошкільних та лікувально-профілактичних закладів, а й чисельності бібліотек та клубів.

Значне загострення економічної кризи можна простежити й у сфері сільського господарства - у головній виробничій сфері сільських територій. Найбільша площа сільськогосподарських угідь (3977,6 тис. га) зосереджена в підприємствах, що мали у власності та користуванні понад 10000 га. У результаті підприємс- тва практично монополізували переробку сільськогосподарської сировини та реалізацію товарної продукції. Монополізація земельних угідь призводить до занепаду малого й середнього бізнесу на селі, фермерства (Tryhuba et al., 2019).

В Україні 53 \% посівних площ України перебуває під зерновими та зернобобовими культурами, а технічні займають 33,6 \%, коренеплоди, бульбоплоди, овочеві культури, продовольчі баштанні та кормові культури - по 6,7 \% посівних площ. Тому виробництво зерна займає значне місце серед інших галузей рослинництва. Зернове виробництво - це галузь, продукція якої завжди була, є й буде одним із найважливіших джерел багатств будь-якої держави.

Рентабельність сільськогосподарського виробництва, i, відповідно, родючість грунтів залежать від обсягів внесення мінеральних та органічних добрив. Як бачимо 3 рис. 2, впродовж 2000-2018 рр. спостерігається тенденція до збільшення обсягів внесення мінеральних добрив, хоча досягнути рівня 1990 р. не вдалось.

Згідно зі статистичними даними впродовж 20002018 рр. обсяги внесених органічних добрив, навпаки, скоротилося з 28,4 млн т до 10,6 млн т (рис. 3). 


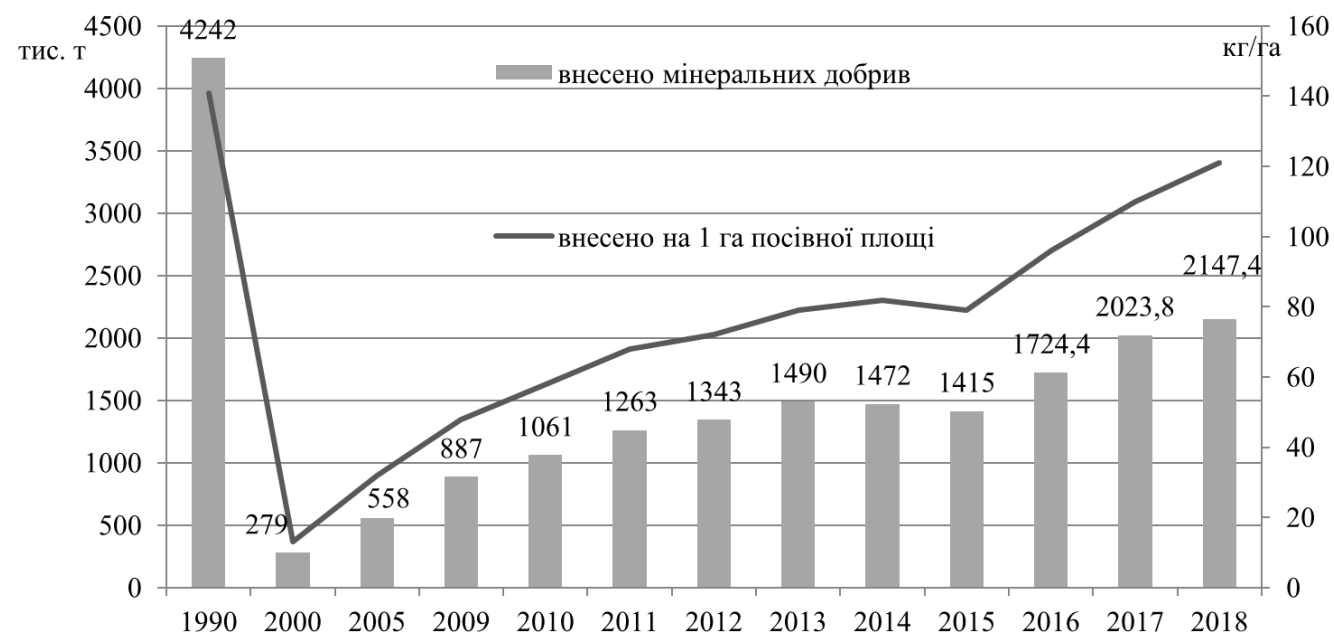

Рис. 2. Динаміка внесення мінеральних добрив підприсмствами в Україні Джерело: побудовано авторами на основі статистичних даних (Derzhavna sluzhba statystyky Ukrainy, 2019)

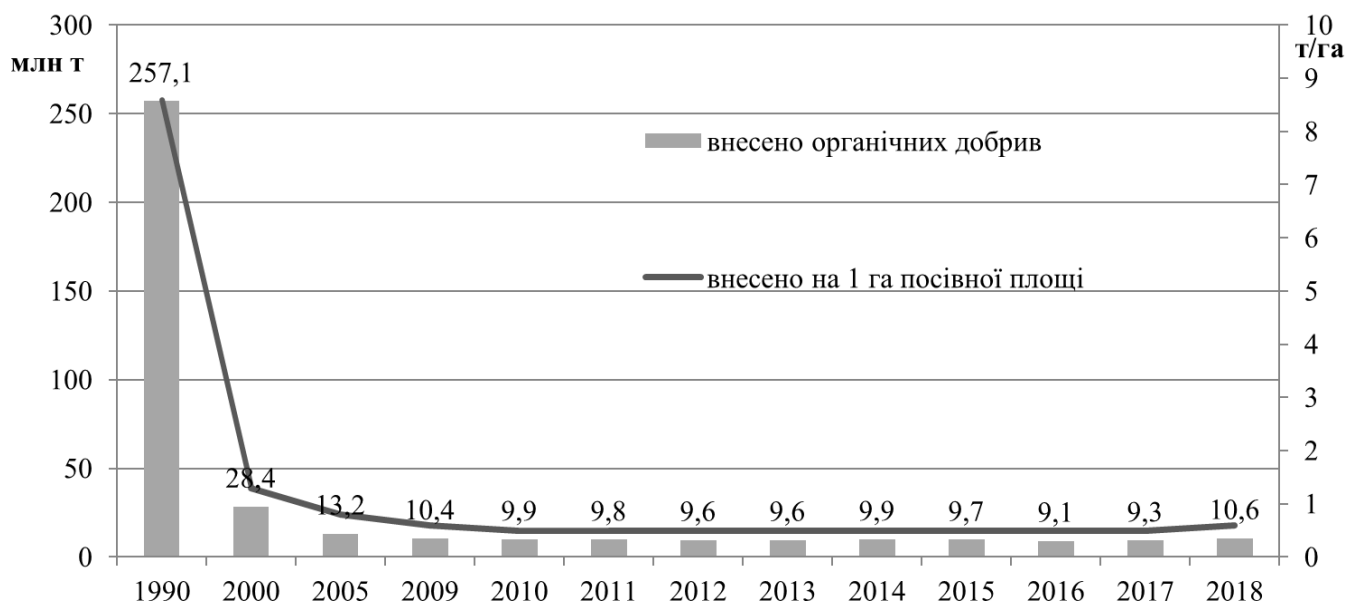

Рис. 3. Динаміка внесення органічних добрив підприємствами в Україні

Джерело: побудовано авторами на основі статистичних даних (Derzhavna sluzhba statystyky Ukrainy, 2019)

За останні десятиліття спостерігаємо погіршення стану грунтів. Сприяння розвитку органічного виробництва як одного із дієвих напрямів диверсифікації сільськогосподарської діяльності дозволить зменшити деградаційні процеси землекористування та отримати позитивні соціально-економічні результати.

Серед них соціальними результатами обгрунтованої диверсифікаційної діяльності підприємств можна віднести підвищення рівня зайнятості на селі, подолання бідності, розвиток соціальної інфраструктури, можливість залучення інвестицій у соціальну сферу, підвищення якості надання послуг, реалізацію соціальних проектів на території сільських, селищних та міських об'єднаних територіальних громадах, виробництво соціально значущих товарів, забезпечення життєдіяльності сільських жителів.

У порівнянні з основними цілями диверсифікації сільськогосподарського виробництва та несільськогосподарської діяльності, диверсифікація організаційноправових форм господарювання має переважно економічний характер і $\epsilon$ спрямованою передусім на отримання економічного ефекту - прибутку. Проте диверсифікація організаційно-правових форм господарювання сприяє розширенню потенційних можли- востей підприємницьких структур та дотриманню принципів соціального та екологічного менеджменту. Важливого значення набувають посилення соціальної, економічної та екологічної відповідальності підприємництва на сільських територіях. Це передбачає збалансування інтересів усіх стейкхолдерів, інвестуванні доходів у соціальну сферу, участі у соціальних проектах, виробництві екологічно безпечних продуктів харчування, раціональному використанні природних ресурсів, безвідходному виробництві та утилізації відходів. Диверсифікація джерел фінансування розвитку сільських територій спрямована на залучення не лише бюджетних коштів, а й коштів фізичних та юридичних осіб, міжнародних фондів 3 метою фінансування проектів соціального, економічного та екологічного розвитку сільських громад.

Як бачимо, диверсифікація виступає дієвим інструментом реалізації стратегічних цілей сталого розвитку та посилення конкурентних переваг сільських територій в умовах нестабільності та швидко змінюваного середовища. Залучення інвестицій у розвиток сільських територій і та їх диверсифікований розвиток із врахуванням регіональних особливостей сприятимуть створенню робочих місць; зростан- 
ню доходів сільських жителів; відродженню місцевих народних промислів, звичаїв та ремесл, покращенню благоустрою сіл і зміні свідомості сільських жителів.

\section{Висновки}

В результаті дослідження обгрунтовано концепцію диверсифікованого розвитку сільських територій в контексті досягнення цілей їх сталого розвитку. Виявлено, що на вибір того чи іншого напряму диверсифікації розвитку (сільськогосподарського виробництва, несільськогосподарської діяльності, організаційноправових форм господарювання, джерел фінансування розвитку сільських територій) впливають внутрішні та зовнішні чинники. Серед внутрішніх чинників соціальні (структура сільського населення, умови життя населення, ситуація на ринку праці, стан соціальної інфраструктури), економічні (забезпеченість сільськогосподарськими угіддями, стан диверсифікації сільськогосподарської та несільськогосподарської діяльності, обсяг інвестицій у розвиток економіки, рівень та структура доходів домогосподарств на сільських територіях), екологічні (рівень забруднення атмосферного повітря, ситуація з відходами, використанням прісної води, внесенням добрив у грунти, виробкою та відновленням лісів, рівень обсягів інвестицій на охорону навколишнього природнього середовища). До зовнішніх чинників впливу на сталий розвитку сільських територій віднесено: політичне становище в країні та світі; наслідки і результати процесу децентралізації; ефективність державних програм підтримки розвитку сільської місцевості й сільського господарства; рівень попиту та пропозиції на товари й послуги, які виробляються на відповідній території тощо.

Перспективи подальших досліджень. Подальші дослідження стосуватимуться факторного аналізу інтегрального індексу сталого розвитку сільських територій в Україні та розробки науково-практичних рекомендацій вибору та реалізації напрямків диверсифікації в об'єднаних територіальних громадах.

\section{References}

Akimova, L. M., Khomiuk, N. L., Bezena, I. M., Lytvynchuk, I. L., \& Petroye, O. (2020). Planning of socioeconomic development of the territories (experience of European Union). International Journal of Management (IJM), 11(4), 638-646. doi: 10.34218/IJM.11.4.2020.054.
Borodina, O. M. (2012). Sotsioekonomichnyi rozvytok silskoho hospodarstva i sela: suchasnyi vymir. NAN Ukrainy; In-t ekon. ta prohnozuv. Kyiv (in Ukrainian).

Derzhavna sluzhba statystyky Ukrainy: ofits. veb-sait: ukrain. versiia. URL: http://www.ukrstat.gov.ua/ (in Ukrainian).

Feduniak, I. O., \& Pidluzhna, O. B. (2019). Normatyvnopravove zabezpechennia derzhavnoi pidtrymky staloho rozvytku silskykh terytorii ta turyzmu. Efektyvna ekonomika. 10. URL: http://www.economy.nayka.com.ua/?op=1\&z=7318. doi: 10.32702/2307-2105-2019.10.48 (in Ukrainian).

Khomiuk, N. L., \& Pavlikha, N. V. (2019). Kontseptualni pidkhody do rozvytku silskykh terytorii $\mathrm{v}$ umovakh detsentralizatsii. Rehionalna ekonomika, 3(93), 71-78. doi: 10.36818/1562-0905-2019-3-7 (in Ukrainian).

Khomiuk, N. L., \& Pavlikha, N. V. (2020). Directions of diversification of agricultural production in Ukraine on the basis of sustainable development. Scientific Messenger of Lviv National University of Veterinary Medicine and Biotechnologies. Series: Economical Sciences, 22(95), 45-51. doi: 10.32718/nvlvet-e9508 (in Ukrainian).

Khomiuk, N., Bochko, O., Pavlikha, N., Demchuk, A., Stashchuk, O., Shmatkovska, T., \& Naumenko, N. (2020). Economic modeling of sustainable rural development under the conditions of decentralization: a case study of Ukraine. Scientific Papers. Series: Management, Economic Engineering in Agriculture and Rural Development, 20(3), 317-332. URL: http://managementjournal.usamv.ro/index.php/scientif ic-papers/current.

Lupenko, Yu. O. (2017). Stan ta perspektyvy staloho rozvytku silskykh terytorii. Ekonomika APK, 6, 7-10 (in Ukrainian).

Report of the World Commission on Environment and Development (1987). Our Common Future. United Nations, 247.

Tryhuba, A., Pavlikha, N., Rudynets, M., Tryhuba, I., Grabovets, V., Skalyga M., Tsymbaliuk, I., Khomiuk, N., \& Fedorchuk Moroz, V. (2019). Studying the influence of production conditions on the content of operations in logistic systems of milk collection. Eastern-European Journal of Enterprise Technologies, 3/3(99), 50-63. doi: 10.15587/1729-4061.2019.171052.

Zahorskyi, V. S., \& Borshchuk, Ye. M. (2019). Teoretykoprykladni aspekty doslidzhennia staloho rozvytku silskykh terytorii Ukrainy. Efektyvnist derzhavnoho upravlinnia, 2(59), 1. doi: 10.33990/20704011.59.2019.178413 (in Ukrainian). 